\title{
New conodont data from a Devonian-Carboniferous succession in the central sector of the Betic Cordillera (SE Spain)
}

\author{
Pilar NAVAS-PAREJO ${ }^{1,2 *}$, Rosario RODRÍGUEZ-CAÑERO² \& Agustín MARTÍN-ALGARRA2
}

${ }^{1}$ Estación Regional del Noroeste, Instituto de Geología, UNAM, 83000 Hermosillo, Mexico; pilarnpg@geologia.unam.mx

${ }^{2}$ Departamento de Estratigrafía y Paleontología, Universidad de Granada, 18071 Granada, Spain; png@ugr.es; charorc@ugr.es; agustin@ugr.es

* Corresponding author

Navas-Parejo, P., Rodríguez-Cañero, R. \& Martín-Algarra, A. 2015. New conodont data from a Devonian-Carboniferous succession in the central sector of the Betic Cordillera (SE Spain). [Nuevos datos de conodontos de una sucesión DevonoCarbonífera del sector central de la Cordillera Bética (SE España)]. Spanish Journal of Palaeontology, 30 (1), $133-146$.

\section{ABSTRACT}

A new Paleozoic outcrop in the Malaguide Complex of the central sector of the Betic Cordillera has provided the conodont species Palmatolepis angularis, Palmatolepis crepida, Palmatolepis quadrantinodosalobata, and Palmatolepis regularis, that identify the Late and Latest crepida zones (Famennian, Late Devonian). In the same outcrop, but in geometrically lower beds, the presence of Gnathodus bilineatus romulus indicates a late Visean to latest Serpukhovian age (Early Carboniferous). This is the first time these both ages are recorded in the area. These findings confirm the intense thrust tectonics affecting the Malaguide rocks in the area, and allow us to correlate this outcrop with other better-known sectors of the Malaguide Complex, affirming the presence of the Falcoña and Almogia formations, as well as that of Upper Devonian strata in a stratigraphic position equivalent to the Santi Petri Fm, but with very different facies.

Keywords: Biostratigraphy, Famennian, Visean, Piar Group, Malaguide Complex.

\section{RESUMEN}

Un nuevo afloramiento del Paleozoico maláguide en el sector central de la Cordillera Bética ha proporcionado algunas especies de conodontos como Palmatolepis angularis, Palmatolepis crepida, Palmatolepis quadrantinodosalobata y Palmatolepis regularis, que han permitido identificar las biozonas superior y más superior de crepida (Fameniense, Devónico Superior). En el mismo afloramiento, pero en capas geométricamente subyacentes, la presencia de Gnathodus bilineatus romulus indica una edad Viseense superior-Serpukhoviense más inferior (Carbonífero Inferior). Este es el primer registro de estas edades en esta área. Estos hallazgos confirman la intensa tectónica cabalgante que afecta a las rocas maláguides en el área y permiten correlacionar este afloramiento con otros sectores mejor conocidos del Complejo Maláguide, confirmando la presencia de las formaciones Falcoña y Almogía, así como la de niveles del Devónico Superior en una posición estratigráfica equivalente a la Formación Santi Petri, pero con facies muy diferentes.

Palabras clave: Bioestratigrafía, Fameniense, Viseense, Grupo Piar, Complejo Maláguide. 


\section{INTRODUCTION}

In the Betic Cordillera, pre-Mesozoic strata appear almost solely in the Internal Domain (also known as Alboran Domain) but they are mostly made up of metamorphic rocks. Consequently, very rare evidence of the presence of fossils has been found there, except for the Malaguide Complex. In spite of strong Alpine (and pre-Alpine) tectonic deformation, the Paleozoic rocks of the Malaguide Complex still preserve their original stratigraphic and sedimentological features. The whole Malaguide Paleozoic succession was included in the Piar Formation by Soediono (1971) and Geel (1973). Later, it was ranked as Piar Group (Martín-Algarra, 1987).

Many studies on the litho- and biostratigraphy of the Piar Group have been published, and Upper Ordovician to Upper Carboniferous rocks have been dated mainly by means of conodonts (e.g., Kockel, 1959, 1963; Kockel \& Stoppel, 1962; Roep \& Mac Gillavry, 1962; RodríguezCañero, 1993; O’Dogherty et al., 2000; Rodríguez-Cañero et al., 2010; Navas-Parejo et al., 2012; Rodríguez-Cañero \& Martín-Algarra, 2014). Only a few of these studies, however, have been carried out in the central sector of the Betic Cordillera, with very rare fossil findings (Foucault \& Paquet, 1970, 1971; García-Dueñas \& Navarro-Vilá, 1976; Navarro-Vilá \& García-Dueñas, 1979). Herbig (1984) and Heekeren (2003) studied in detail the microfacies and fossil content of the boulders and pebbles included in the youngest formation of the Piar Group, the Marbella Conglomerate Formation. They identified several shallow marine facies bearing Devonian and Carboniferous fossils. More recently, Navas-Parejo et al. (2011) described the first conodonts found in the central sector of the Malaguide Complex, which indicate an Emsiam age (Early Devonian).

The aim of this paper is to report the first Late Devonian and Early Carboniferous conodont fauna found in a new outcrop in the central sector of the Malaguide Complex, which was only preliminarily studied by Navas-Parejo (2012). These findings allow correlating the Malaguide Paleozoic in this area with that of other better-known sectors of the Betic Cordillera.

\section{GEOLOGICAL SETTING}

The Malaguide Complex makes the topmost part of the Internal Domain, and thrusts widely over the Alpujarride Complex although, in most places, the original contact has been modified by younger extensional tectonics. Malaguide Paleozoic rocks are mainly slates and greywackes, predominantly of turbiditic origin and poor in fossils. They constitute the Piar Group, which consists of five lithostratigraphic formations, from bottom to top, Morales Fm, Santi Petri Fm, Falcoña Fm, Almogia Fm, and
Marbella Fm (Martín-Algarra et al., 2004, and references therein).

The widest outcrop of the Malaguide Complex in the central sector of the Betic Cordillera is located $\mathrm{N}$ of Granada (Fig. 1a), along a narrow WSW-ENE topographic depression to the $\mathrm{S}$ of Sierra Arana, which was defined by Blumenthal \& Fallot (1935) as the Cogollos Vega Zone (Fig. 1b). They are predominantly siliciclastic rocks tectonically sandwiched between Meso-Cenozoic carbonate rocks, either to the $\mathrm{N}$ (belonging to the Frontal Units of the Internal Domain) or to the S (belonging to the Alpujarride Complex). Because of that, the Malaguide rocks are strongly folded, with common subvertical dip, local stratigraphic inversion and intense internal imbrication characterised, mainly, by southward-directed backthrusting.

The Morales Fm is the oldest formation of the Piar Group, although it still remains undated everywhere. This formation is made up of fine-grained slates and shales alternating with compact quartz-feldspathic and micaceous sandstone beds (Martín-Algarra, 1987, and references therein). A metric to decametric, laterally discontinuous horizon of strongly deformed clast-supported conglomerates (Conglomerado de Cantos Estirados) crops out quite frequently towards the top of the Morales Fm. In the Cogollos Vega Zone, the Morales Fm is tectonically laminated or reduced to a few metres, and the outrops are limited to the southernmost and tectonically lower thrust slices.

The Santi Petri Fm contains clastic facies that range from fine-grained terrigenous limestones to calcareous greywackes. It is usually made up of strongly folded turbiditic limestones known as calizas alabeadas (Orueta, 1917), which alternate with greywackes and pelites similar to those of the Morales Fm. In spite of lacking fossils, a pre-Carboniferous age (probably Devonian) is commonly accepted, because of its stratigraphic position below welldated levels of the Falcoña Fm. In the Cogollos Vega Zone the Santi Petri Fm is also tectonically thinned in most sites, and is exclusively present in the lowermost and southernmost tectonic slices. In the studied area, this formation is mainly constituted by pelites and greywackes and only occasionally preserves isolated and laterally discontinuous intercalations of its most typical calizas alabeadas facies.

The Falcoña Fm is subdivided into two members (Herbig, 1983). The lower and most typical member is made up of thin-bedded, usually black or dark (when unweathered) radiolarian cherts commonly known as lydites. These rocks probably had an original thickness of a few tens of metres but they have been strongly thinned to a few metres in most sites, due to intense disharmonic folding and tectonic stretching that make the outcrops of the whole formation laterally discontinuous. This lower member has been dated as Tournaisian by means of radiolarians in the Malaga area (O'Dogherty et al., 2000). 


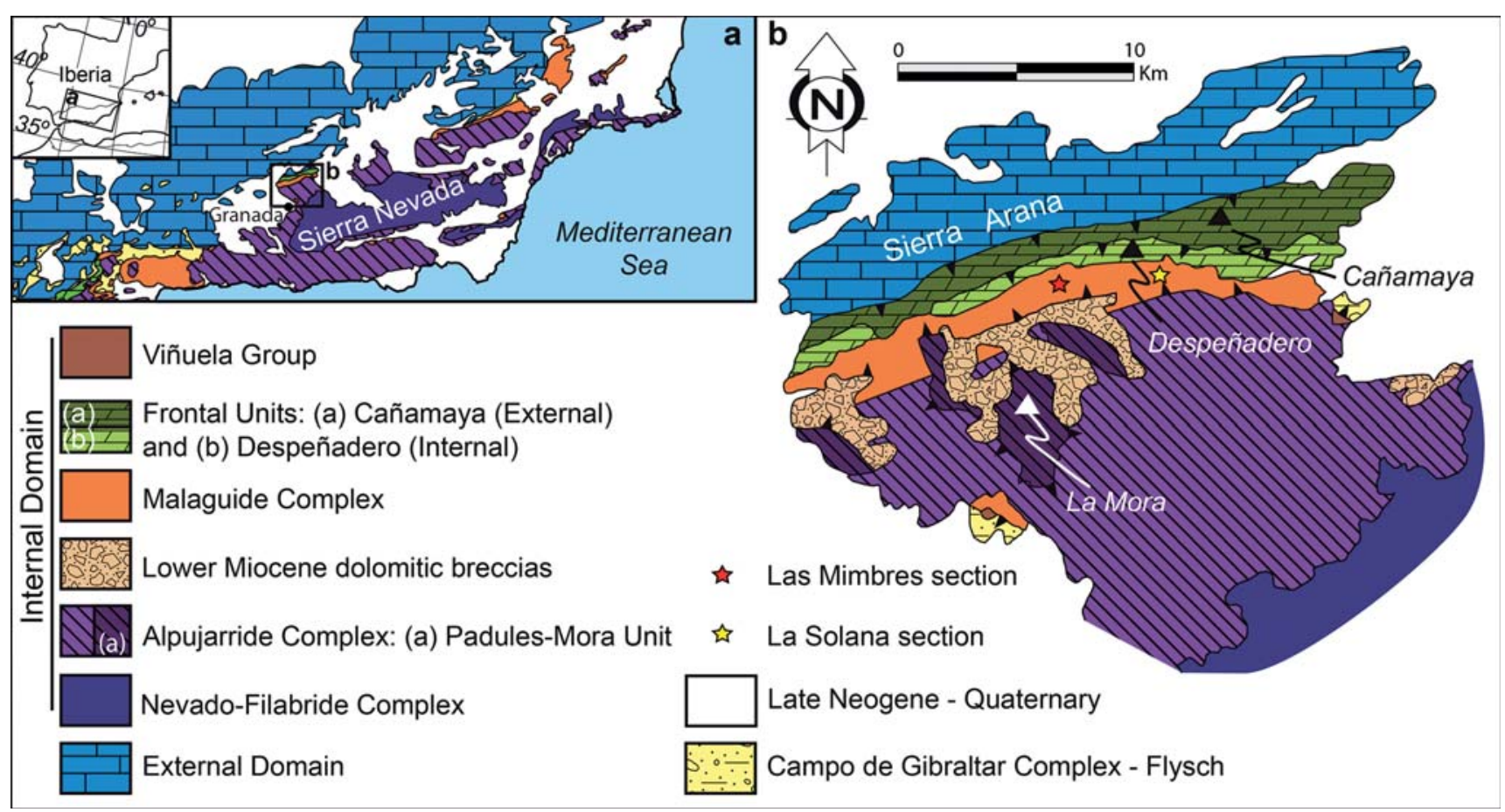

Figure 1. Geological sketch maps. a) The central-eastern Betic Cordillera. b) The Cogollos Vega Zone.

The upper member of the Falcoña Fm is calcareous, and it is preserved in only a very few sites. It consists of micritic limestones (sometimes also including chert nodules), which have been dated by means of conodonts as upper Visean in both western and eastern Malaguide outcrops (Rodríguez-Cañero, 1993; Rodríguez-Cañero \& Guerra-Merchán, 1996; O’Dogherty et al., 2000; NavasParejo et al., 2008). Within the Cogollos Vega Zone, both members of the Falcoña Fm, but predominantly the lower one, appear as scattered outcrops a few square metres wide included within larger outcrops of brownish and olivegreen pelites of probably Devonian-Carboniferous age.

The Almogia Fm lies (in most sites unconformably) on the Falcoña and/or older formations. It constitutes a turbiditic megasequence of greywackes and pelites, with some conglomerate intercalations, usually thinningand fining-upwards, and it shows typical Variscan Culm facies. The lowest part of this formation is the Retamares member (Kockel \& Stoppel, 1962; Herbig, 1984), which is made up of medium- to coarse-grained and thickto very thick-bedded greywackes and conglomerates. Limestone clasts contained in the conglomerates of several western Malaguide outcrops have released Middle to Late Devonian conodonts and other fossils (Buchroitner et al., 1980; Herbig, 1984; Rodríguez-Cañero, 1993). In the Cogollos Vega Zone the Almogia Fm is dominated by pelites, although turbiditic greywackes and fine-grained conglomerates locally appear. Because of that, and where the Falcoña Fm cannot be observed in outcrops due to tectonic thinning and/or soil cover, it can be very difficult to distinguish the pelites belonging to the Almogia Fm from those related to underlying formations. Nonetheless, the Almogia Fm pelites are usually slightly less intensely foliated than those associated with the Santi Petri and Morales formations.

The youngest formation of the Piar Group is the Marbella Fm, although the top of the Almogia Formation in most Malaguide outcrops is an unconformity surface below the Triassic redbeds with Pseudoverrucano lithofacies of the Saladilla Fm (Roep, 1972; Perrone et al., 2006; Perri et al., 2013). The Marbella Fm rests disconformably on the Almogia Fm, from which it can be easily distinguished by its massive appearance, slightly calcareous nature and much coarser grain size (Herbig, 1984). In addition, the Marbella conglomerates usually contain cobbles and boulders, up to several metres large, of granite and gneiss, and especially of limestones bearing Carboniferous shallow marine fossils (Herbig, 1984, 1986; Herbig \& Mamet, 1985; Heekeren, 2003). The Marbella Fm is well represented in the Cogollos Vega Zone, forming a narrow and laterally discontinuous belt along its northern border. This belt corresponds to the uppermost Malaguide tectonic slice in the Cogollos Vega Zone, which is bounded by N-dipping steep faults and which is also stratigraphically characterised by the absence of the Morales and Santi Petri formations within its stratigraphic succession. Pre-Carboniferous beds in this uppermost Malaguide tectonic slice are dominated by pelites with laterally discontinuous limestone lenses including Devonian fossils (dacryoconarids: Foucault \& Paquet, 1970; and conodonts: Navas-Parejo et al., 2011); 
these pelites and limestones show very different facies with respect to those typical of the Morales and Santi Petri formations.

\section{RESULTS}

\subsection{La Solana successions}

The studied outcrop is located to the east of the path from the Venta del Tejarillo to the Cortijo de la Mina, along a forest track towards the Cortijo de la Solana and Sillar Alta crossing Paleozoic, Triassic and strongly thinned Jurassic beds. The outcrop is located at coordinates:

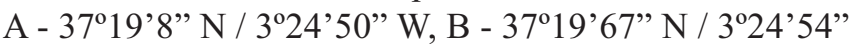
W (Fig. 2a), and at an elevation of about $1,290 \mathrm{~m}$. As described below, field and conodont data from this outcrop allow clearly distinguishing two independent stratigraphic successions, southern and northern, bounded by a subvertical fault (Fig. 2b).

The southern Solana succession (Figs 2b, 5) tectonically overlies continental (fluvial) red Triassic pelites and sandstones, and starts with about $15 \mathrm{~m}$ of Devonian olive-green pelites and greywackes with very thin-bedded yellowish limestones bearing dacryoconarids (visible only under the hand lens) towards the lowest part (Fig. 3a). The succession is gently dipping to the north and continues with about $10 \mathrm{~m}$ of well bedded but intensely crushed and folded black cherts (lydites) followed, in normal stratigraphic succession, by a few metres of greenish and reddish slates topped by platy conodont-bearing limestones with black chert nodules (Fig. 3b). It continues, in apparently conformable succession and in gradual transition, with several metres (about 15-20 m of minimum stratigraphic thickness) of light brown-silvery slates dipping to the NW and that, in its northern part, are strongly folded by SE-vergent chevron-like folds. To the N, these pelites are

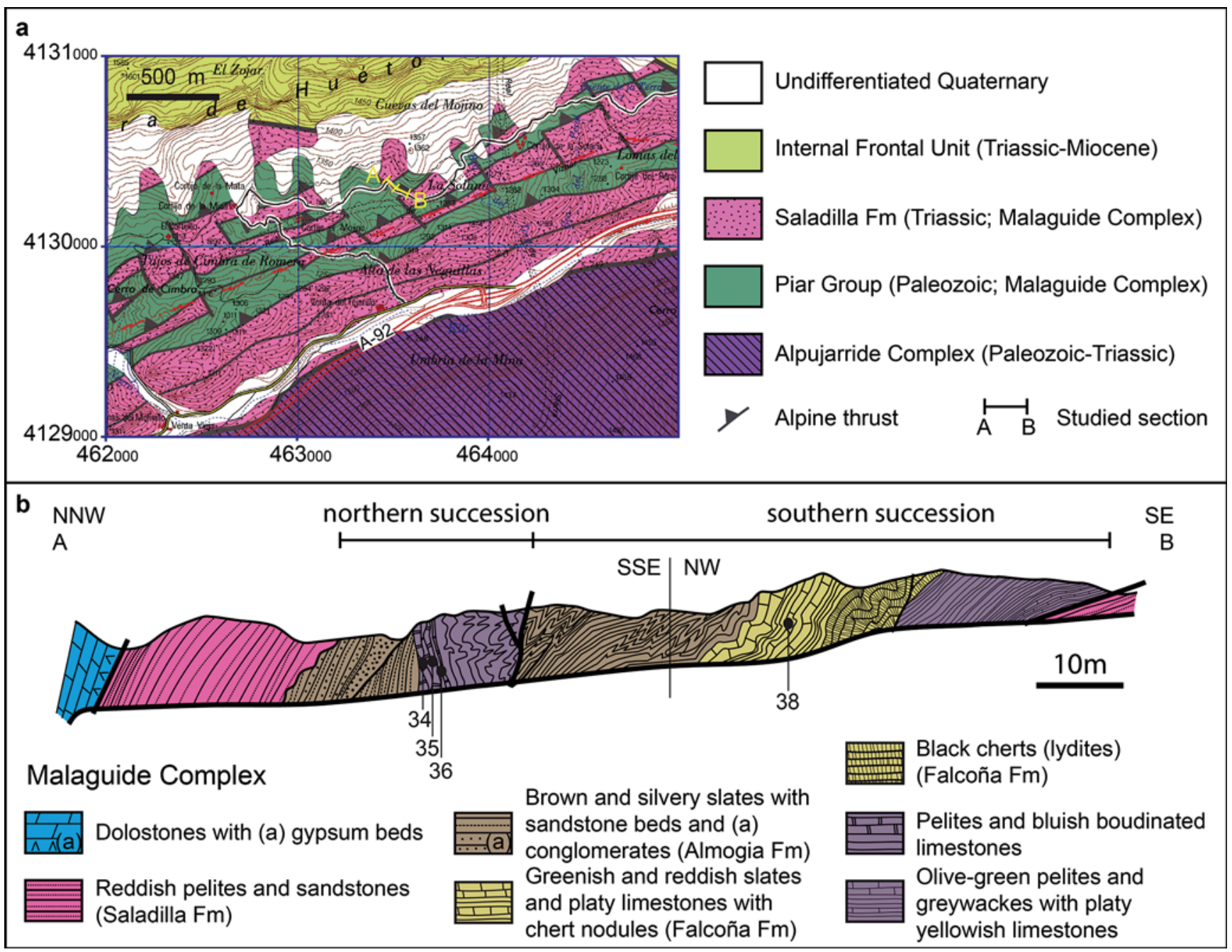

Figure 2. a) Geological map of the studied area (modified from Navarro-Vilá \& García-Dueñas, 1979). b) Geological cross section in La Solana area with location of the studied samples. 
bound, by a steep fault, which constitutes the tectonic boundary with the northern succession.

The northern succession of the La Solana outcrop starts with a few metres of strongly sheared pelites with subvertical attitude, which are quite similar to those on the other side of the fault. These pelites are gradually followed by bedded subvertical to slightly dipping $\mathrm{N}$ and bluish limestone beds, strongly faulted and boudinated, and less than $2 \mathrm{~m}$ thick. These limestones include thin pelite intercalations in its southern part, and are more calcareous and massive in its northern part. These limestones are followed by a few metres of foliated silvery slates (Fig. 3c) including some fine grained and thinbedded sandstone beds. The latter beds are unconformably covered by a channeled conglomerate up to three metres thick, including granule- to pebble-sized clasts of black lydite, white quartzite, greywacke and gneiss (Fig. 3d). This conglomerate is conformably followed by brownishgreenish slates and greywackes that intercalate $\mathrm{dm}$-thick and locally channeled subvertical beds of conglomerates,
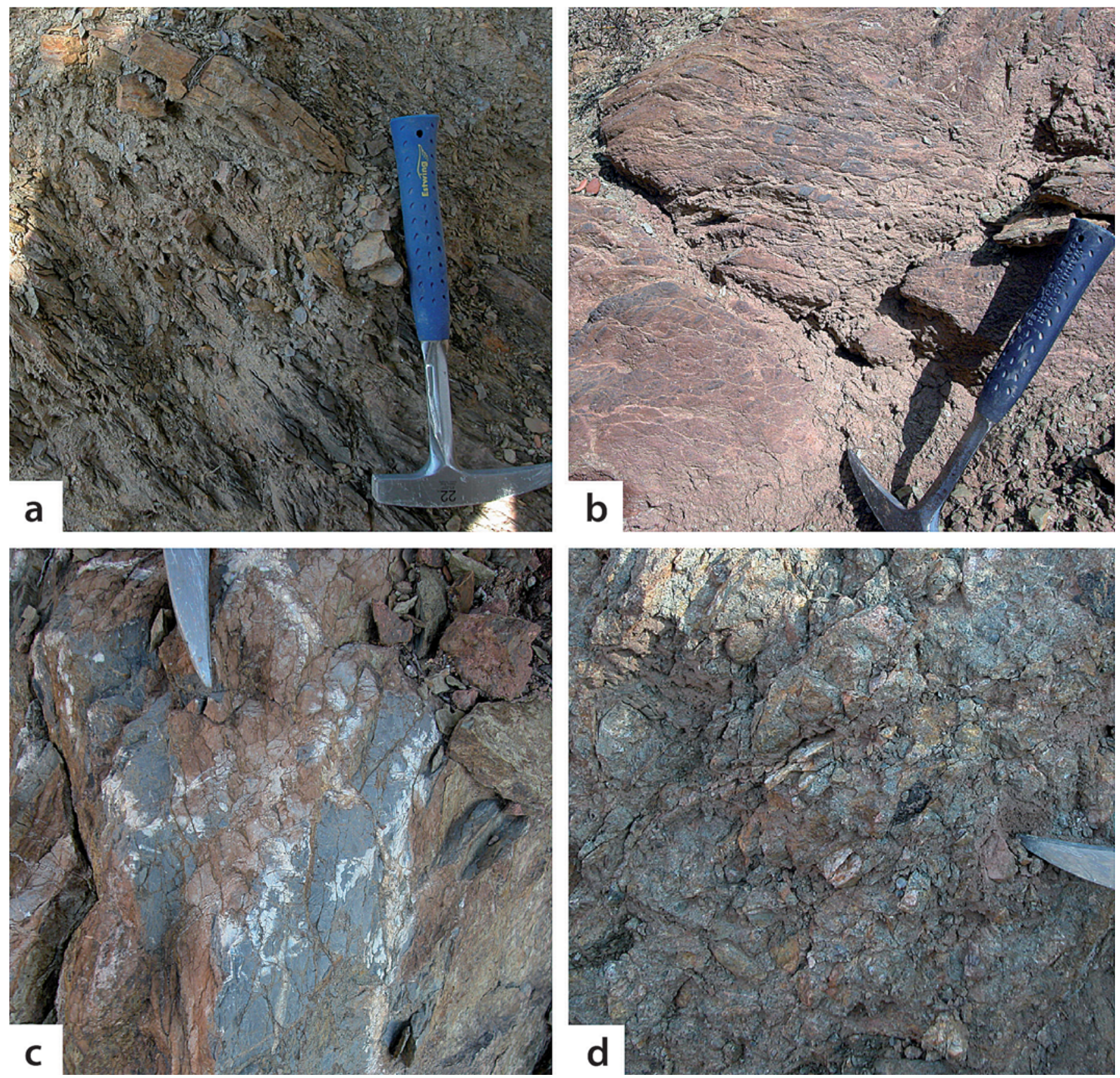

Figure 3. Paleozoic rocks of the La Solana section. a) Olive-green pelites with thin-bedded yellowish limestones bearing dacryoconarids. b) Limestones with chert nodules. c) Strongly deformed bluish limestones. d) Conglomerates including clasts of black lydite, white quartzite, greywacke and gneiss. 
compositionally equivalent to the lower one but finergrained. Finally, the Paleozoic succession is unconformably covered by a few metres of cross-bedded red sandstones and pelites with typical Triassic continental redbed facies. Some traces of gypsum locally appear towards the stratigraphic contact of the redbeds with overlying, probably lowermost Jurassic, strongly stretched dolostones.

\subsection{Materials and methods}

Five samples taken in La Solana section and processed for conodont studies using standard acetic acid dissolution (Jeppsson et al., 1999) provided conodont elements or fragments. Samples 34, 35 and 36 were taken from the massive bluish limestone beds (Figs 2b, 5). Samples 37 and 38 were collected from the platy limestones with black chert nodules (Figs 2b, 5) but conodont remnants from sample 37 could not be classified. Conodont elements recovered are housed in the Departamento de Estratigrafía y Paleontología (Universidad de Granada). Catalogue numbers are indicated in the caption of the Figure 4. Additional samples, collected from the platy limestone beds bearing dacryoconarids, of the stratigraphically and tectonically lowest part of the section, have not provided yet any conodont fragment.

\subsection{Systematic palaeontology}

The systematic study below is based exclusively on $\mathrm{P}_{1}$ elements (Purnell et al., 2000). Although during the last decades multielemental taxonomy is preferred in conodont systematic studies, $\mathrm{P}_{1}$ elements usually contain the fundamental information for taxonomic classification at species level and, therefore, for biostratigraphy, which is the aim of this paper. Non- $\mathrm{P}_{1}$ elements, which made part of the conodont apparatuses, are usually shared between species within the same genus (see for example Grayson et al., 1990 for the genus Gnathodus, or Metzger, 1994 for the genus Palmatolepis).

The suprageneric classification followed was that proposed by Sweet (1988).

Phylum CHORDATA Bateson, 1886

Class CONODONTI Branson, 1938

Order OZARKODINIDA Dzik, 1976

Family Palmatolepidae Sweet, 1988

Genus Palmatolepis Ulrich \& Bassler, 1926

Type species - Palmatolepis perlobata Ulrich \& Bassler, 1926

\section{Palmatolepis angularis Klapper, Uyeno, Armstrong \&} Telford, 2004

(Fig. 4.3)
1994 Palmatolepis aff. P. gracilis gracilis; Metzger, p. 629, figs. 17.4, 17.5 .

*2004 Palmatolepis angularis n.sp.; Klapper et al., p. 379 , figs. 7.2-7.3.

Remarks. $\mathrm{P}_{1}$ elements of this species have an intermediate morphology between those of Palmatolepis minuta minuta Branson \& Mehl and Palmatolepis gracilis gracilis Branson \& Mehl. In P. angularis the dorsal/ posterior carina of $\mathrm{P}_{1}$ elements is straight although angled from ventral/anterior carina, and the central node is offset from ventral/anterior carina. The carina of $P$. g. gracilis is more nearly straight but sigmoidal. The platform of $P$. minuta minuta is broader than that of $P$. angularis.

Stratigraphic occurrence. From the upper part of the Middle crepida Zone to the lower part of the Late marginifera Zone (Klapper et al., 2004).

Material. One $\mathrm{P}_{1}$ element from sample 34, and three $\mathrm{P}_{1}$ elements from sample 35 .

Palmatolepis crepida Sannemann, 1955a

(Fig. 4.1)

1955a Palmatolepis crepida n.sp.; Sannemann, p. 134, Pl. 6, Fig. 21.

1993 Palmatolepis crepida; Ji \& Ziegler, p. 59, Pl. 22, figs. 1-7.

2012 Palmatolepis crepida; Mossoni et al., p. 22, Fig. 5.18

Remarks. $\mathrm{P}_{1}$ elements found have a drop-shaped outline and a very weakly developed dorsal/posterior carina. Rostral/outer side of the platform without lateral lobe.

Stratigraphic occurrence. From the lowest part of the Early crepida Zone up to the Early rhomboidea Zone (Ji \& Ziegler, 1993).

Material. One $\mathrm{P}_{1}$ element from sample 34, and two $\mathrm{P}_{1}$ elements from sample 36 .

Palmatolepis quadrantinodosalobata Sannemann, 1955b (Fig. 4.2)

1955 a Palmatolepis quadrantinodosalobata; Sannemann, p. 135, Pl. 1, Fig. 5.

1994 Palmatolepis quadrantinodosalobata; Metzger, p.636, figs. 10.16-10.17.

2004 Palmatolepis quadrantinodosalobata; Klapper et al., figs. 5.20-5.22.

2007 Palmatolepis quadrantinodosalobata; Over, figs. 13.13-13.15, 17.9. 


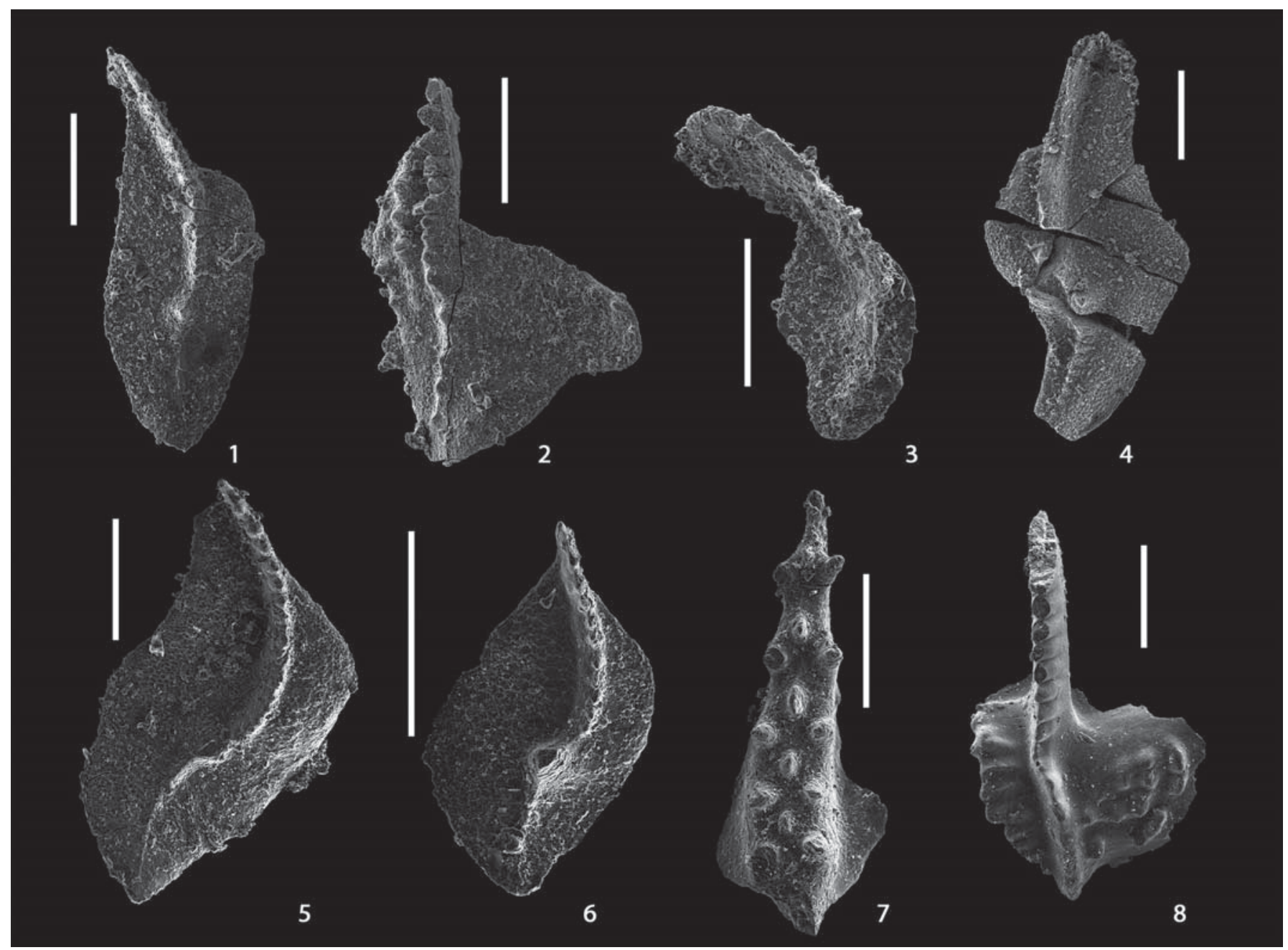

Figure 4. Late Devonian and Early Carboniferous conodonts from La Solana section. All are oral/upper views of $\mathrm{P}_{1}$ elements. Scale bars $200 \mu \mathrm{m}$. 1) Palmatolepis crepida; specimen 08P-34-008. 2) Palmatolepis quadrantinodosalobata; specimen 08P-34012. 3) Palmatolepis angularis; specimen 08P-34-010. 4) Palmatolepis tenuipunctata; specimen 08P-34-013. 5) Palmatolepis regularis; specimen 08P-35-015. 6) Palmatolepis regularis; specimen 08P-36-022. 7) Icriodus alternatus alternatus morphotype 1; specimen 08P-36 020. 8) Gnathodus bilineatus romulus; specimen 08P-38-024. Labelling indicates the following: a) first two digits followed by a capital letter (08P): year of sampling (2008) and collector (Pilar Navas-Parejo); b) second two digits: sample number (location in the outcrop design reproduced in Fig. $2 \mathrm{~b}$, and in the stratigraphic column of the Fig. 5); and c) three last digits: specimen number.

Remarks. One of the $\mathrm{P}_{1}$ elements found (Fig. 4.2) has two rows of nodes in the ventral/anterior caudal/ inner platform being parallel to the blade, which is almost straight. Other elements found show a single row of nodes in the ventral/anterior caudal/posterior margin of the platform. In all the specimens found, a well-developed rostral/outer lobe is present.

Stratigraphic occurrence. From the lowest part of the Early crepida Zone to the Early rhomboidea Zone (Ji \& Ziegler, 1993).

Material. One $P_{1}$ element from sample 34, two $P_{1}$ elements from sample 35, and three $\mathrm{P}_{1}$ elements from sample 36.
Palmatolepis regularis Cooper, 1931

(Figs 4.5-4.6)

1962 Palmatolepis cf. regularis; Ziegler, p. 75-77, Pl. 6, figs. 20-24.

1994 Palmatolepis cf. P. regularis; Metzger, p. 636, figs. 17.16-17, 17.21.

2004 Palmatolepis regularis; Klapper et al., p. 381, figs. 7.28, 7.31.

2007 Palmatolepis regularis; Over, p. 1213, figs. 14.2114.23 .

Remarks. The studied $\mathrm{P}_{1}$ elements show sigmoidal carina and sigmoidal outline. Rostral/outer platform is 
broader near the central node and does not present rostral/ outer lobe. Dorsal/posterior carina is weakly developed.

The holotype figured by Cooper (1931) is a mold of the aboral/lower surface of a $\mathrm{P}_{1}$ element. As a result of this, many authors since then had made reference to this species as Palmatolepis cf. P. regularis. Over (2007) reillustrated the holotype as well as paratypes under the same sample number, which are also molds but include both parts and counterparts.

Stratigraphic occurrence. Late crepida Zone (Metzger, 1994; Over, 2007).

Material. One $\mathrm{P}_{1}$ element from sample 35, and one $\mathrm{P}_{1}$ element from sample 36 .

Palmatolepis tenuipunctata Sannemann, 1955a

(Fig. 4.4)

1955a Palmatolepis tenuipunctata n.sp.; Sannemann, p. 136, Pl. 6, Fig. 22.

1975 Palmatolepis tenuipunctata; Druce, p. 173, Pl. 60, figs. 1a-4b.

1993 Palmatolepis tenuipunctata; Ji \& Ziegler, p. 72, P1. 19, figs. 1-6.

2012 Palmatolepis tenuipunctata; Mossoni et al., p. 29, Fig. 5.13 .

Remarks. The main features of $\mathrm{P}_{1}$ elements of Palmatolepis tenuipunctata are a small rostral/outer lobe, a slightly sigmoidal carina and a shagreen ornamented oral/ upper platform surface. The presence of the rostral/outer lobe distinguishes this species from other subspecies of Palmatolepis glabra group.

Stratigraphic occurrence. From the lowest part of the Late triangularis Zone up to the Latest crepida Zone (Ji \& Ziegler, 1993).

Material. One $\mathrm{P}_{1}$ element from sample 34, and two $\mathrm{P}_{1}$ elements from sample 36.

Family Gnathodontidae Sweet, 1988

Genus Gnathodus Pander, 1856

Type species - Polygnathus bilineatus Roundy, 1926

Gnathodus bilineatus romulus Meischner \& Nemyrovska, 1998

(Fig. 4.8)

1998 Gnathodus bilineatus romulus n.ssp.; Meischner \& Nemyrovska, p. 436, 438, Pl. 3, figs. 11, 12, 15, 16, 22.

2005 Gnathodus bilineatus romulus; Nemyrovska, p. 33-34, Pl. 5, figs. 9, 13; Pl. 7, Fig. 13.
Remarks. The $\mathrm{P}_{1}$ element found is characterised by a high and moderately wide parapet, with transverse ridges, which runs parallel to the carina and does not reach the dorsal/posterior tip. The rostral/outer cusp has a semirounded to subquadrate outline and shows two rows of nodes parallel to the rostral/outer margin. The nodes are moderately wide and some of them are fused. A deep trough between parapet and carina is present, mostly in the dorsal/posterior part.

Stratigraphic occurrence. Meischner \& Nemyrovska (1998) recommended to set the base of the G. bilineatus Zone with the first appearance of G. bilineatus romulus. According to Nemyrovska (2005), the distribution of this subspecies in Spain ranges from late Visean through the earliest Serpukhovian (Early Carboniferous).

Material. One $\mathrm{P}_{1}$ element from sample 38 .

Order PRIONIODONTIDA Dzik, 1976

Family Icriodontidae Müller \& Müller, 1957

Genus Icriodus Branson \& Mehl, 1938

Type species - Icriodus expansus Branson \& Mehl, 1938.

Icriodus alternatus alternatus Branson \& Mehl, 1934 morphotype 1 Sandberg \& Dreesen, 1984

(Fig. 4.7)

1966 Icriodus alternatus; Anderson, p. 405, P1. 52, figs. 11-12.

1984 Icriodus alternatus alternatus morphotype 1; Sandberg \& Dreesen, p. 158-159, Pl. 2, figs. 5-11.

2000 Icriodus alternatus alternatus; Over \& Rhodes, p. 109, Fig. 6.4 .

2014 Icriodus alternatus alternatus; Rodríguez-Cañero \& Martín-Algarra, Fig. 10.2.

Remarks. $\mathrm{P}_{1}$ elements of Icriodus alternatus alternatus are characterised by a straight platform where the denticles of the central row alternate with the denticles of the lateral rows. The main feature of the morphotype 1 of this subspecies is the strong lateral compression of the denticles in the central row.

Stratigraphic occurrence. Low in the Late rhenana Zone into the Late crepida Zone (Sandberg \& Dreesen, 1984).

Material. One $\mathrm{P}_{1}$ element from sample 36.

\subsection{Biostratigraphy}

As stated above, only four samples of the La Solana outcrop have yielded classifiable conodont elements (Fig. 5). 


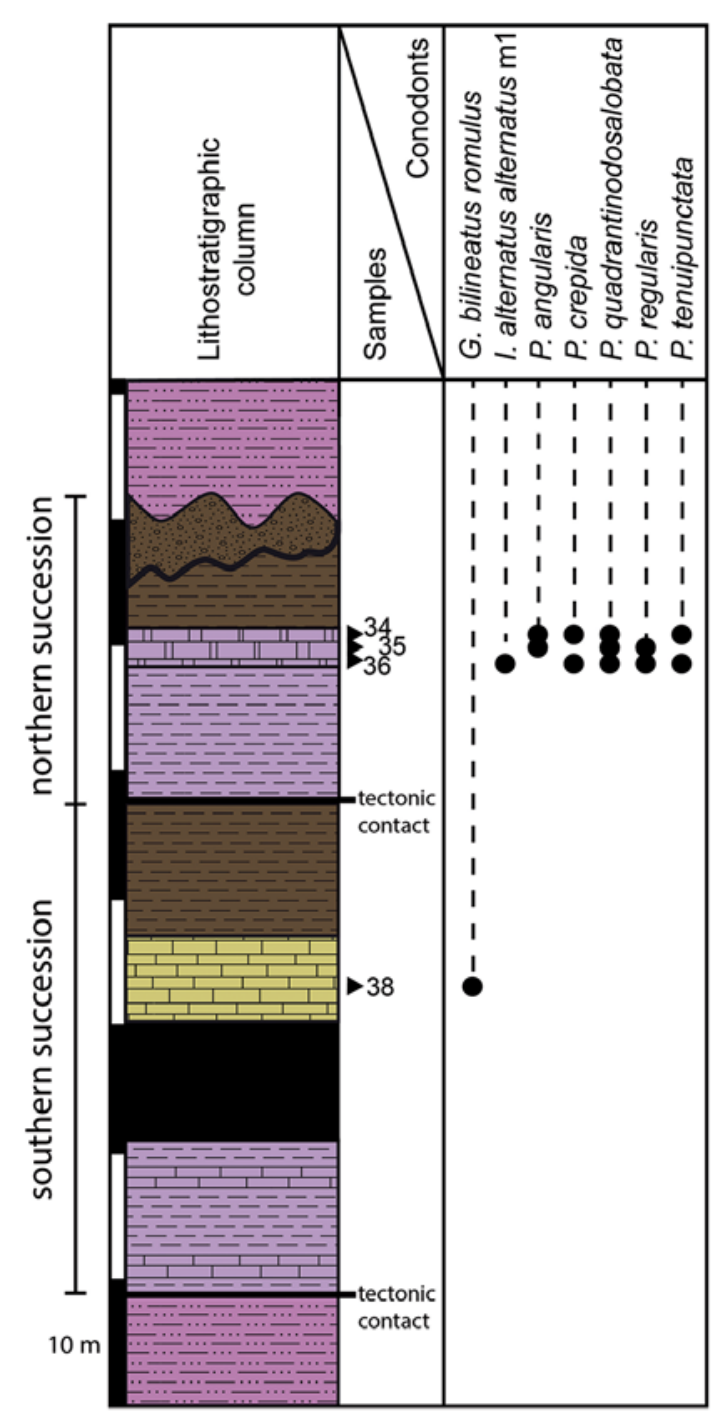

Triassic reddish pelites and sandstones (Saladilla Fm)

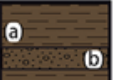

(a) Brown and silvery slates with sandstone beds and (b) conglomerates (Almogia Fm)

Lower Carboniferous slates and platy limestones with chert nodules (Falcoña Fm)

Lower Carboniferous lydites (Falcoña Fm)

Upper Devonian medium-bedded bluish limestones

(a) Devonian olive-green pelites and greywackes with (b) platy yellowish limestone intercalations bearing dacryoconarids

Figure 5. Lithostratigraphic column of the La Solana outcrop corresponding to two tectonically stacked different Paleozoic successions, with the location of the productive samples and the distribution of Late Devonian (Famennian) and Early Carboniferous (Visean-Serpukhovian) conodonts found, the tectonic contacts, and the erosion surfaces.
The oldest conodont associations have been found in the bluish limestones of the northern (and geometrically upper) succession of the La Solana outcrop (samples 34, 35 and 36), whereas the youngest association has been found in the middle part of the southern succession that, according to bedding attitude (dipping NW: Fig. 2b) appear in a geometric position below the northern succession (sample 38).

Sample 34 released Palmatolepis angularis, $P$. crepida, $P$. quadrantinodosalobata, and $P$. tenuipunctata. This conodont association indicates an age from the upper part of the Middle crepida Zone up to the Latest crepida Zone (Famennian; Late Devonian).

Sample 35 yielded $P$. angularis, $P$. quadrantinodosalobata, and $P$. regularis. This conodont fauna corresponds to the Late crepida Zone (Famennian; Late Devonian).

Sample 36 released Icriodus alternatus alternatus morphotype $1, P$. quadrantinodosalobata, $P$. regularis, and $P$. tenuipunctata. This association also belongs to the Late crepida Zone (Famennian; Late Devonian).

The youngest conodont fauna has been found in sample 38 , coming from geometrically lower beds within the same outcrop, where only one but very well preserved $\mathrm{P}_{1}$ element assigned to Gnathodus bilineatus romulus has been found. This fauna indicates an age ranging from the G. bilineatus Zone (Visean; Early Carboniferous) to the Lochriea ziegleri Zone (Serpukhovian; Early Carboniferous).

\section{DISCUSSION AND CONCLUSIONS}

Late Devonian and Early Carboniferous conodonts have been found for the first time in the central outcrops of the Malaguide Complex N of Granada (Cogollos Vega Zone). This record allows correlating the Malaguide Paleozoic in this area with better-known sectors, as the western Betic Cordillera, where the main formations of the Piar Group were defined.

The oldest Devonian beds well dated by conodonts at La Solana are Famennian in age. They have appeared in the northern succession, within boudinated subvertical limestone beds that are stratigraphically attached to the pelites that bound, by a subvertical fault, with the folded and southward vergent pelites that constitute the stratigraphic upper part of the southern succession (Fig. 2b). Nevertheless, the geometrically lowest beds (according to bedding attitude) that appear in the southern succession of La Solana outcrop contain dacryoconarids. Unfortunately, these beds have not released yet any conodont element, but dacryoconarids became extinct in Frasnian times and, consequently, these beds must be stratigraphically the oldest of the La Solana outcrop, either Frasnian or older. In addition the youngest conodont 
associations at La Solana come from the limestones that are stratigraphically sandwiched between the pelites of the upper part of the southern succession and the lydites that overlie the dacryoconarid-bearing beds. These conodonts clearly demonstrate that the age of the limestones is Viseanearliest Serpukhovian and that the pelites stratigraphically overlying these limestones in gradual transition must be younger, probably Serpukhovian. Consequently field and biostratigraphic data evidence that two independent stratigraphic successions (northern and southern) bounded by a steep fault and corresponding to independent tectonic units must be differentiated within the studied outcrop at La Solana. The fault, probably a southward-verging backthrust, separates the Upper Devonian beds of the stratigraphic lower part of the northern succession from the Lower Carboniferous beds of the stratigraphic upper part of the southern succession.

The base of the tectonically lower unit corresponds to a low angle fault gently dipping northwards, so that its Paleozoic rocks thrust onto red Triassic sandstones. The stratigraphic succession starts with Devonian slates containing thin limestone beds bearing dacryoconarids near to their lowest part (Frasnian or older). These facies do not correspond to any typical facies of the Santi Petri or of the Morales formations and, then, should be included in an independent, yet unnamed, formation. These beds are stratigraphically and conformably covered by cherts (lydites) followed by a few beds of greenish and reddish slates topped by the limestones with black chert nodules dated by conodonts as Visean-earliest Serpukhovian in sample 38. The latter rocks undoubtedly correspond to the lower and upper members of the Falcoña Fm, respectively. The pelites lying conformably on the Lower Carboniferous limestones would constitute either the base of the Almogia Fm or, maybe, an independent stratigraphic pelitic interval that would predate the typical lowest beds of that formation, which corresponds to the Retamares member, formed by coarse-grained and thick-bedded clastic sediments in most outcrops where it appears.

The stratigraphic succession of the upper tectonic unit starts, after a steep fault, with a pelitic interval that gradually changes upwards to Famennian limestones of the Late and Latest crepida zones. In the same way as the Devonian beds of the lower tectonic units (southern succession) these Devonian pelites and limestones neither show the typical facies of the Morales or Santi Petri formations. These beds are followed by latest Devonian (?) or Carboniferous pelites and fine-grained sandstones, and, after an erosion surface, by coarse-grained clastics showing the typical features of the basal beds of the Almogia Fm (Retamares member). The absence of the Falcoña Fm in this upper section can be reasonably explained by submarine erosion before deposition of the Almogia Fm lower beds. This would explain the common presence of clasts of black radiolarian chert in the conglomerates of this upper tectonic unit, which were probably eroded from the lower member of the Falcoña Fm. In addition, this constitutes an independent evidence of the youngest Early Carboniferous age of the Almogía Fm, as it is commonly accepted.

Late Devonian (Famennian) conodonts have been described in several outcrops of the Malaguide Complex and some of them have been found in cobbles or pebbles included in the Retamares member of the Almogia Fm (Herbig, 1983; Rodríguez-Cañero, 1993, 1995). Devonian fossils have also been detected within limestone clasts of the Marbella Fm (Buchroithner et al., 1980; Herbig, 1984, 1986; Herbig \& Mamet, 1985) and, recently, within clasts (in that case exclusively of Frasnian age) from a conglomeratic horizon below the Falcoña Fm (RodríguezCañero \& Martín-Algarra, 2014). Devonian carbonate beds, from Lochkovian to Famennian, have been dated, mainly by conodonts and mostly in the western sector of the Betic Cordillera (Rodríguez-Cañero, 1993, 1995; Martín-Algarra et al., 2009) and, recently, also in the eastern sector (NavasParejo, 2012). Nevertheless, in these areas these conodontbearing limestones are not stratigraphically related to the calizas alabeadas of the Santi Petri Fm but make part of independent successions deposited in different parts of the Malaguide Devonian realm, with the Santi Petri Fm representing the most distal and deepest turbiditic areas of the basin (Navas-Parejo, 2012; Rodríguez-Cañero \& Martín-Algarra, 2014). The same situation is observed in the Cogollos Vega Zone, both in the two stratigraphic successions characterized within the La Solana outcrop (this study) and also in the Las Mimbres outcrop, where the Emsian was dated by Navas-Parejo et al. (2011). All these outcrops make part of upper Malaguide imbricates that are tectonically independent of those in lower tectonic position, whose stratigraphic succession includes the Morales Fm and the Santi Petri Fm. This indicates that at least two different palaeoenvironmental areas are recorded in the pre-Carboniferous successions of the Malaguide Complex, and that both areas can also be recognized in the Cogollos Vega Zone. Further biostratigraphic studies and mapping on these fossiliferous successions equivalent to the Santi Petri Fm are needed in order to understand their exact origin and palaeoenvironmental significance.

The upper member of the Falcoña Fm has been dated as late Visean in several outcrops of the western (RodríguezCañero, 1993; Rodríguez-Cañero \& Guerra-Merchán, 1996) and eastern sectors of the Betic Cordillera (NavasParejo et al., 2008). The presence of Gnathodus bilineatus romulus in the carbonate levels above the lydites in the lower (southern) succession at La Solana allows confirming the occurrence of the Falcoña Fm in the Cogollos Vega Zone. Nevertheless, the upper stratigraphic range of this species is slightly younger than that of the Falcoña Fm according to available biostratigraphic studies in the Malaguide Complex. In any case, this finding also confirms 
the presence of the Almogia-like pelites above the Falcoña Fm limestones, and also above the Famennian limestones in the studied upper tectonic unit (northern succession), in that case with the typical conglomeratic lithofacies of its stratigraphically lower part (Retamares member).

\section{ACKNOWLEDGEMENTS}

This is a contribution to projects CGL2012-32169 (MCIDGICYT) and P11-RNM-7067 (Junta de Andalucía), research groups RNM-208 and RNM-3715 (Junta de Andalucía), and IGCP Project 596 "Climate change and biodiversity patterns in the Mid-Paleozoic". We acknowledge Pablo Plasencia, José Ignacio ValenzuelaRíos, and the Associate Editor Matías Reolid for conscientiously reviewing the manuscript and for editing work. We gratefully thank I. Guerra Tschuschke and I. Sánchez Almazo (Centro de Instrumentación Cientifica, University of Granada) for their assistance with the SEM.

\section{REFERENCES}

Anderson, W.I. 1966. Upper Devonian conodonts and the Devonian-Mississippian boundary of North-Central Iowa. Journal of Paleontology, 40, 395-415.

Bateson, W. 1886. Anchestry of the Chordata. Quarterly Journal of Microscopical Sciences, 26, 535-571.

Blumenthal, M. \& Fallot, P. 1935. Observations géologiques sur la Sierra Arana entre Grenade et Guadix. Memorias de la Sociedad Española de Historia Natural, XVIII, 1-74.

Branson, E.B. 1938. Stratigraphy and paleontology of the Lower Mississipian of Missouri. University of Missouri Studies, 13, 1-208.

Branson, E.B. \& Mehl, M.G. 1934. Conodonts from the Grassy Creek Shale of Missouri. University of Missouri Studies, 8, 171-259.

Branson, E.B. \& Mehl, M.G. 1938. The conodont genus Icriodus and its stratigraphic distribution. Journal of Paleontology, 12, 156-166.

Buchroithner, M., Flügel, E., Flügel, H.W. \& Stattegger, K. 1980. Mikrofazies, Fossilien und Herkunft der KalkGerölle im Karbon-"Flysch" der Betischen Kordilleren, Spanien. Facies, 2, 1-54.

Cooper, C.L. 1931. New conodonts from the Woodford formation of Oklahoma. Journal of Paleontology, 5, 230-243.

Druce, E.C. 1975. Conodont biostratigraphy of the Upper Devonian Reef Complexes of the Canning Basin, Western Australia. Australian Government Publishing Service, Canberra.

Dzik, J. 1976. Remarks on the evolution of Ordovician conodonts. Acta Palaeontologica Polonica, 21, 395-445.
Foucault, A. \& Paquet, J. 1970. La structure de l'ouest de la Sierra Arana (Province de Grenade, Espagne). Comptes Rendus de l'Académie des Sciences de Paris, 271, 16-19.

Foucault, A. \& Paquet, J. 1971. Sur l'importance d'une tectogènese hercynienne dans la région centrale des Cordillères Bétiques (S. de la Arana, prov. Grenade, Espagne). Comptes Rendus de l'Académie des Sciences de Paris, 272, 2756-2758.

García-Dueñas, V. \& Navarro-Vilá, F. 1976. Alpujarrides, Malaguides, et autres unités allochtones au Nord de la Sierra Nevada (Cordillères Bétiques, Andalousie). Bulletin de la Societé géologique de France, 18(7), 641-648.

Geel, T. 1973. The geology of the Betic of Málaga, the Subbetic and the zone between these two units in the Vélez Rubio area (southern Spain). GUA Papers of Geology, Series 1, 1-181.

Grayson, R.C., Merrill, G.K. \& Lambert, L.L. 1990. Carboniferous gnathodontid conodont apparatuses: evidence of a dual origin for Pennsylvanian taxa. Courier Forschungsinstitut Senckenberg, 118, 353-396.

Heekeren, O. 2003. Karbonatmikrofazielle, sedimentologische und stratigraphische Untersuchungen im Karbon-Flysch der Zone von Cogollos Vega (Betische Kordillere, Südspanien). Diplomarbeit thesis, University of Cologne (unpublished).

Herbig, H.G. 1983. El Carbonífero de las Cordilleras Béticas. In: Carbonífero y Pérmico de España (ed. Martínez-Díaz, C.). Ministerio de Industria y Energía-IGME, Madrid, 343-356.

Herbig, H.G. 1984. Rekonstruktion eines nicht mehr existenten Sedimentationsraume - Die Kalkgerölle im Karbon-Flysch der Malagiden (Betische Kordillere, Südspanien). Facies, 11, 1-108.

Herbig, H.G. 1986. Rugosa und Heterocorallia aus OberviséGeröllen der Marbella-Formation (Betische Kordillere, Südspanien). Paläontologische Zeitschrift, 60, 189-225.

Herbig, H.G. \& Mamet, B. 1985. Stratigraphy of the limestone boulders, Marbella Formation (Betic Cordillera, Southern Spain). Comptes Rendus 10 Congrès International de Stratigraphie et de Géologie du Carbonifère, 1, 199-212.

Jeppsson, L., Anehus, R. \& Fredholm, D. 1999. The optimal acetate buffered acetic acid technique for extracting phosphatic fossils. Journal of Paleontology, 73, 964-972.

Ji, Q. \& Ziegler, W. 1993. The Lali section: An excellent reference section for Upper Devonian in south China. Courier Forschunginstitut Senckenberg, 157, 1-182.

Klapper, G., Uyeno, T.T., Armstrong, D.K. \& Telford, P.G. 2004. Conodonts of the Williams Island and Long Rapids Formations (Upper Devonian, Frasnian-Famennian) of the Onakawana B drillhole, Moose River basin, Northern Ontario, with a revision of Lower Famennian species. Journal of Paleontology, 78, 371-387.

Kockel, F. 1959. Conodontos del Paleozoico de Málaga. Notas y comunicaciones del Instituto Geológico y Minero de España, 53, 149-164.

Kockel, F. 1963. Die Geologie des Gebietes zwischen dem Rio Guadalhorce und dem Plateau von Ronda (Spanien). Geologie Jahrb, 81, 413-480. 
Kockel, F. \& Stoppel, D. 1962. Nuevos hallazgos de conodontos y algunos cortes en el Paleozoico de Málaga (Sur de España). Notas y comunicaciones del Instituto Geológico y Minero de España, 68, 133-170.

Martín-Algarra, A. 1987. Evolución geológica alpina del contacto entre las Zonas Internas y las Zonas Externas de la Cordillera Bética. PhD thesis, Universidad de Granada.

Martín-Algarra, A., Rodríguez-Cañero, R., O’Dogherty, L., Sánchez-Navas, A. \& Ruiz-Cruz, M.D. 2004. Estratigrafía. Paleozoico ¿y más antiguo? (Grupo Piar). In: Geología de España (ed. Vera, J.A.). Sociedad Geológica de EspañaInstituto Geológico y Minero de España, Madrid, 401-404.

Martín-Algarra, A., Mazzoli, S., Perrone, V., RodríguezCañero, R. \& Navas-Parejo, P. 2009. Variscan Tectonics in the Malaguide Complex (Betic Cordillera, Southern Spain): Stratigraphic and Structural Alpine versus Pre-Alpine Constraints from the Ardales Area (Province of Malaga). I. Stratigraphy. Journal of Geology, 117, 241-262.

Meischner, D. \& Nemyrovska, T. 1998. Origin of Gnathodus bilineatus (Roundy, 1926) related to goniatite zonation in Rheinisches Schiefergebirge, Germany. Bollettino della Società Paleontologica Italiana, 37(2-3), 427-442.

Metzger, R.A. 1994. Multielement reconstructions of Palmatolepis and Polygnathus (Upper Devonian, Fammenian) from the Canning Basin, Australia, and Bactrian Mountain, Nevada. Journal of Paleontology, 68, 617-647.

Mossoni, A., Corradini, C. \& Pondrelli, M. 2012. Famennian (Late Devonian) conodonts from the Pizzul West section (Carnic Alps, Italy). Gortania. Geologia, Paleontologia, Paletnologia, 34, 13-36.

Müller, K.J. \& Müller, E.M. 1957. Early Upper Devonian (Independence) conodonts from Iowa, part I. Journal of Paleontology, 31, 1069-1108.

Navarro-Vilá, F. \& García-Dueñas, V. 1979. Geologic Map of Spain (MAGNA); sheet of La Peza (1010), 1:50.000, Instituto Geológico y Minero de España, Madrid.

Navas-Parejo, P. 2012. Paleozoic stratigraphy and Palaeogeography of the Malaguide Complex (Betic Cordillera) and other Western Mediterranean related domains (Calabria-Peloritani Terrane). $\mathrm{PhD}$ Thesis, University of Granada. http://hdl.handle.net/10481/23780

Navas-Parejo, P., Martín-Algarra, A. \& Martínez-Pérez, C. 2011. Primeros datos sobre la presencia de conodontos del Emsiense (Devónico Inferior) en el Complejo Maláguide de la provincia de Granada. Paleontologia i evolució, Memòria especial, 5, 425-429.

Navas-Parejo, P., Rodríguez-Cañero, R. \& Martín-Algarra, A. 2008. Conodontos del Carbonífero maláguide en Vélez Rubio (Cordillera Bética, SE Spain). Geo-Temas, 10, 1273-1276.

Navas-Parejo, P., Rodríguez-Cañero, R. \& Martín-Algarra, A. 2012. Primer registro de un horizonte estratigráfico hemipelágico con conodontos del Carbonífero Superior en el Complejo Maláguide oriental (Cordillera Bética). Geogaceta, 52, 81-84.

Nemyrovska, T.I. with an appendix by Samankassou, E. 2005. Late Viséan/early Serpukhovian conodont succession from the Triollo section, Palencia (Cantabrian Mountains, Spain). Scripta Geologica, 129, 13-89.

O’Dogherty, L., Rodriguez-Cañero, R., Gursky, H.J., MartinAlgarra, A. \& Caridroit, M. 2000. New data on Lower Carboniferous stratigraphy and palaeogeography of the Malaguide Complex (Betic Cordillera, Southern Spain). Comptes Rendus de l'Académie des Sciences de Paris Earth and Planetary Sciences, 331, 533-541.

Orueta, D. 1917. Estudio geológico y petrográfico de la Serranía de Ronda. Memorias del Instituto Geológico de España, 1, 1-567.

Over, D.J. 2007. Conodont biostratigraphy of the Chattanooga shale, Middle and Upper Devonian, Southern Appalachian Basin, Eastern United States. Journal of Paleontology, 81, 1194-1217.

Over, D.J. \& Rhodes, M.K. 2000. Conodonts from the Upper Olentangy shale (Upper Devonian, Central Ohio) and stratigraphy across the Frasnian-Famennian boundary. Journal of Paleontology, 74, 101-112.

Pander, C.H. 1856. Monographie der fossilen Fische des silurischen System der russisch-baltischen Gouvernements. Akademie der Wissenschaften, St. Petersburg.

Perri, F., Critelli, S., Martín-Algarra, A., Martín-Martín, M., Aiello, M., Mongelli, G., Perrone, V., Sonnino, M., \& Zattin, M. 2013. Triassic redbeds in the Malaguide Complex (Betic Cordillera, Spain): petrography, geochemistry, and geodynamic implications. Earth Science Reviews, 117, 1-28.

Perrone, V., Martín-Algarra, A., Critelli, S., Decandia, F.A., D’Errico, M., Estévez, A., Iannace, A., Lazzarotto, A., Martín-Martín, M., Martín-Rojas, I., Mazzoli, S., Messina, A., Mongelli, G., Vitale, S. \& Zaghloul N.M. 2006. "Verrucano" and "Pseudoverrucano" in the CentralWestern Mediterranean Alpine Chains. In: Tectonics of the Western Mediterranean and North Africa (eds. Moratti, G. \& Chalouan, A.). Geological Society, London, Special Publications, 262, 1-43.

Purnell, M.A., Donoghue, P.C.J. \& Aldridge, R.J. 2000. Orientation and anatomical notation in conodonts. Journal of Paleontology, 74, 113-122.

Rodríguez-Cañero, R. 1993. Contribución al estudio de los conodontos del Paleozoico del Complejo Maláguide (Cordillera Bética). $\mathrm{PhD}$ thesis, University of Málaga (unpublished).

Rodríguez-Cañero, R. 1995. El género Palmatolepis (Ulrich y Bassler) y su aplicación para la detección de biozonas y biofacies en materiales del Complejo Maláguide (Cordillera Bética, España). Revista Española de Paleontología, Número homenaje al Dr. Guillermo Colom, 3-23.

Rodríguez-Cañero, R. \& Guerra-Merchán, A. 1996. Nuevos datos sobre la fauna de conodontos y la edad de la Formación Falcoña (Complejo Maláguide, Cordillera Bética, España). Revista Española de Paleontología, 10, 235-246.

Rodríguez-Cañero, R. \& Martín-Algarra, A. 2014. FrasnianFamennian crisis in the Malaguide Complex (Betic Cordillera, Spain). Terra Nova, 26, 38-54. 
Rodríguez-Cañero, R., Martín-Algarra, A., Sarmiento, G.N. \& Navas-Parejo, P. 2010. First Late Ordovician conodont fauna in the Betic Cordillera (South Spain): a palaeobiogeographical contribution. Terra Nova, 22, 330-340.

Roep, T.B. 1972. Stratigraphy of the "Permo-Triassic" Saladilla formation and its tectonics setting in the Betic of Malaga (Vélez Rubio region, SE Spain). Proceedings of the Koninklijke Nederlandse Academie van Wetenschappen, 75, 223-247.

Roep, T.B. \& Mac Gillavry, H.J. 1962. Preliminary note on the presence of distinct tectonic units in the Betic of Málaga of the Vélez Rubio region (SE Spain). Geologie en Mijnbouw, 41, 423-429.

Roundy, P.V. 1926. Introduction, the microfauna in Mississipian formations of San Saba County, Texas. U.S. Geological Survey Professional Paper, 146, 1-46.

Sandberg, C.A. \& Dreesen, R. 1984. Late Devonian icriodontid biofacies models and alternate shallow-water conodont zonation. Geological Society of America Special Paper, 196, 143-178.
Sannemann, D. 1955a. Oberdevonische Conodonten (to II alpha). Seckenbergiana lethaea, 36, 123-156.

Sannemann, D. 1955b. Beitrag zur Untergliederung des Oberdevons nach Conodontes. Neues Jahrbuch für Geologie und Paläontologie, 100, 324-331.

Soediono, H. 1971. Geological investigations in the Chirivel area, province of Almería - southern Spain. PhD thesis, University of Amsterdam.

Sweet, W.C. 1988. The Conodonta: morphology, taxonomy, paleoecology, and evolutionary history of a long-extinct animal phylum. Oxford Monographs on Geology and Geophysics, Oxford.

Ulrich, E.O. \& Bassler, R. S. 1926. A classification of the toothlike fossils, conodonts, with descriptions of American Devonian and Mississippian species. Proceedings of the United States National Museum, 68, 1-63.

Ziegler, W. 1962. Taxonomie und Phylogenie Oberdevonischer Conodonten und ihre stratigraphische Bedeutung. Abhandlungen des Hessischen Landesamtes für Bodenforschung, 38, 1-166. 
